THE GENERIC NAMES BLANKAARTIA OUDEMANS, 1911, AND TROMBICULOIDES JACOT, 1938 (ACARI: TROMBICULIDAE) ${ }^{1}$

By H. S. FulleR ${ }^{2}$ and G. W. WharToN 3

The generic names of trombiculid mites have been studied recently by several acarologists. Two of the genera have been based on specimens that were incorrectly identified, so that they fall in the category of genera based on misidentified genotypes. The question of what to do concerning these names was referred to Mr. Francis Hemming, Secretary of the International Commission on Zoological Nomenclature. In a letter, he indicated that the concluding portion of Opinion 168 (namely, the portion which states that, where a genus is considered by specialists to be based on a misidentified type species, that name is to be regarded as of doubtful status pending a definite ruling being given by the Commission in the light of data submitted to it by interested specialists) will be omitted from the revision of the rules of zoological nomenclature in which the opinions will be incorporated with the rules. It is therefore necessary either to apply the principle established in Opinion 168 that designations of type species for genera must stand, or to refer the case to the Commission for use of their plenary powers to suspend the rules. Since the Commission can use its plenary powers only when strict application of the rules will result in greater confusion than uniformity, the type designations for the genera Blankaartia and Trombiculoides must be accepted.

Oudemans, 1911, designated Trombidium niloticum Trägårdh, 1904, as type of a new genus Blankaartia (Ent.

${ }^{1}$ Done both at Harvard University and Duke University in connection with research supported by grants-in-aid from the Division of Research Grants and Fellowships of the National Institutes of Health, U. S. Public Health Service.

${ }^{2}$ Department of Microbiology, Harvard University School of Public Health.

${ }^{3}$ Department of Zoology, Duke University, Durham, North Carolina. 
Ber. $3: 123)$. His description of the genus was based on specimens purported to be the larvae of Trombidium niloticum by Trägårdh, although Trägårdh stated that the evidence associating these larvae with adults of Trombidium niloticum was circumstantial and therefore not conclusive. In fact, these larvae can now be recognized as belonging in a different family from the adults. However, according to the rules Blankaartia must retain as genotype Trombidium niloticum Trägårdh, 1904.

Berlese, 1912, proposed the subgeneric name Trägårdhula with the type $T$. nilotica (Träg.) (Redia 8:4). Since Blankaartia and Trägårdhula are based on the same type species they are synonyms.

Thor, 1936, proposed the generic name Pentagonella with Trombidium ardeae Trägårdh, 1904, as type. On the basis of morphological characteristics and geographical considerations it is quite possible that $T$. ardeae and $T$. niloticum are synonyms. However, only rearing experiments will be able to establish their identity. The work of Michener, 1946, has demonstrated that $T$. niloticum and $T$. ardeae are congeneric if not conspecific. Therefore Pentagonella Thor, 1936 , is also a synonym of Blankaartia.

Michener, 1946, reports rearing specimens of Trombicula (Megatrombicula) alleei Ewing, 1926; Trombicula (Megatrombicula) velascoi Boshell and Kerr, 1942; and Trombicula (Megatrombicula) attenuata Michener, 1946. These species he places in the subgenus Megatrombicula Michener, 1946, with Trombicula alleei Ewing, 1926, as type. These three species are also congeneric with $T$. niloticum.

Womersley, 1948, added to the confusion by trying to settle the problem in his own manner without proper regard for the International Rules on Zoological Nomenclature. He accepts as the genotype of Blankaartia the species represented by the larva thought to be Trombidium niloticum Trägårdh by Oudemans. He refers to this species as Blankaartia nilotica (Träg.) on page 83 and as Blankaartia nilotica (Ouds.) on page 84. Actually the species represented by these larvae does not yet have a name. In the same paper Womersley used Trägårdhula nilotica as the valid name for Trombidium niloticum Trägårdh. 
As for the generic names involved, strict application of the rules of priority leads to the following conclusion. Blankaartia Oudemans, 1911 (Type Trombidium niloticum Trägårdh, 1904) has priority over Trägårdhula Berlese, 1912 (Type Trombidium niloticum Trägårdh, 1904) ; Pentagonella Thor, 1936 (Type Trombidium ardeae Trägårdh, 1904) ; and Megatrombicula Michener, 1946 (Type Trombicula alleei Ewing, 1938). All of these names should be applied at the subgeneric level at the present time. The proper name of the species named Trombidium niloticum by Trägårdh is therefore Trombicula (Blankaartia) nilotica (Trägårdh), 1904.

The species represented by the larvae associated with $T$. nilotica (Trägårdh) has never been named. It is therefore necessary to name this species. It is a trombidiid and probably belongs to the subfamily Microtrombidiinae. The adult must be known before the species can be assigned with certainty to a subfamily.

\section{Pseudoblankaartia n. gen.}

Pseudoblankaartia is characterized by Oudemans, 1912, Zool. Jahrb., Supp. 14: 118-119 under the name Blankaartia. The type of Pseudoblankaartia n. gen. is hereby designated as Pseudoblankaartia bequaerti n. sp.

Pseudoblankaartia bequaerti $n$. sp.

$P$. bequaerti is characterized by Oudemans, 1912, Zool. Jahrb., Supp. 14: 119-122 + Figure H. As type of the species we designate the specimen from which Oudemans prepared Figure $\mathrm{H}$.

A similar but less confusing condition exists in the case of Trombiculoides Jacot, 1938. Wharton, 1948, explains the details. Now that the portion of Opinion 168 mentioned above has been repudiated, Ewing's 1946 solution of the problem is correct and Trombiculoides Jacot, 1938 should be considered a synonym of Sericothrombium Berlese, 1910.

\section{REFERENCES}

Berlese, A.

1913. Trombididae Prospetto dei generi e delle specie finora noti. Redia, 8:1-291. 
EwING, H. E.

1946 Notes on the taxonomy of three genera of trombiculid mites (Chigger mites), together with the description of a new genus. Biol. Soc. Wash. Proc., 59:69-72.

Jacot, Arthur PaUl

1938 Thomas Say's free-living mites rediscovered. Psyche, 45:121-132. MICHENER, C. D.

1946 The taxonomy and bionomics of a new subgenus of chigger mites (Acarina, Trombiculinae). Ent. Soc. Amer. Annals, 39:431-445.

Oudemans, A. C.

1911 Arcarologische Aanteekeningen XXXV. Ent. Ber., 3:118-126.

1912 Die bis jetzt bekannten Larven von Thrombidiinae und Erythraeidae. Zool. Jahrb., Suppl., 14:1-230.

1913 Acarologische Aanteekeningen XLVI. Ent. Ber., 3:333-340.

THor, SIG

1936 Neue Gattungen in der Familie Thrombididae W. E. Leach 1814. Zool. Anz, 114:29-32.

Tragardh, IVAR

1904: Results Swedish Zoological Expedition to Egypt and the White Nile 1901. Acariden aus Agypten und dem Sudan. 20:1-124. + tables and figures.

WhaRton, G. W.

1948 The generic name Trombiculoides Jacot, 1938. Psyche, 55:139-140. Womersley, $\mathrm{H}$.

The genus Tragardhula Berlese 1912 (Acarina Trombiculidae). Trans. Roy. Soc. S. Aust., 72:83-90. 

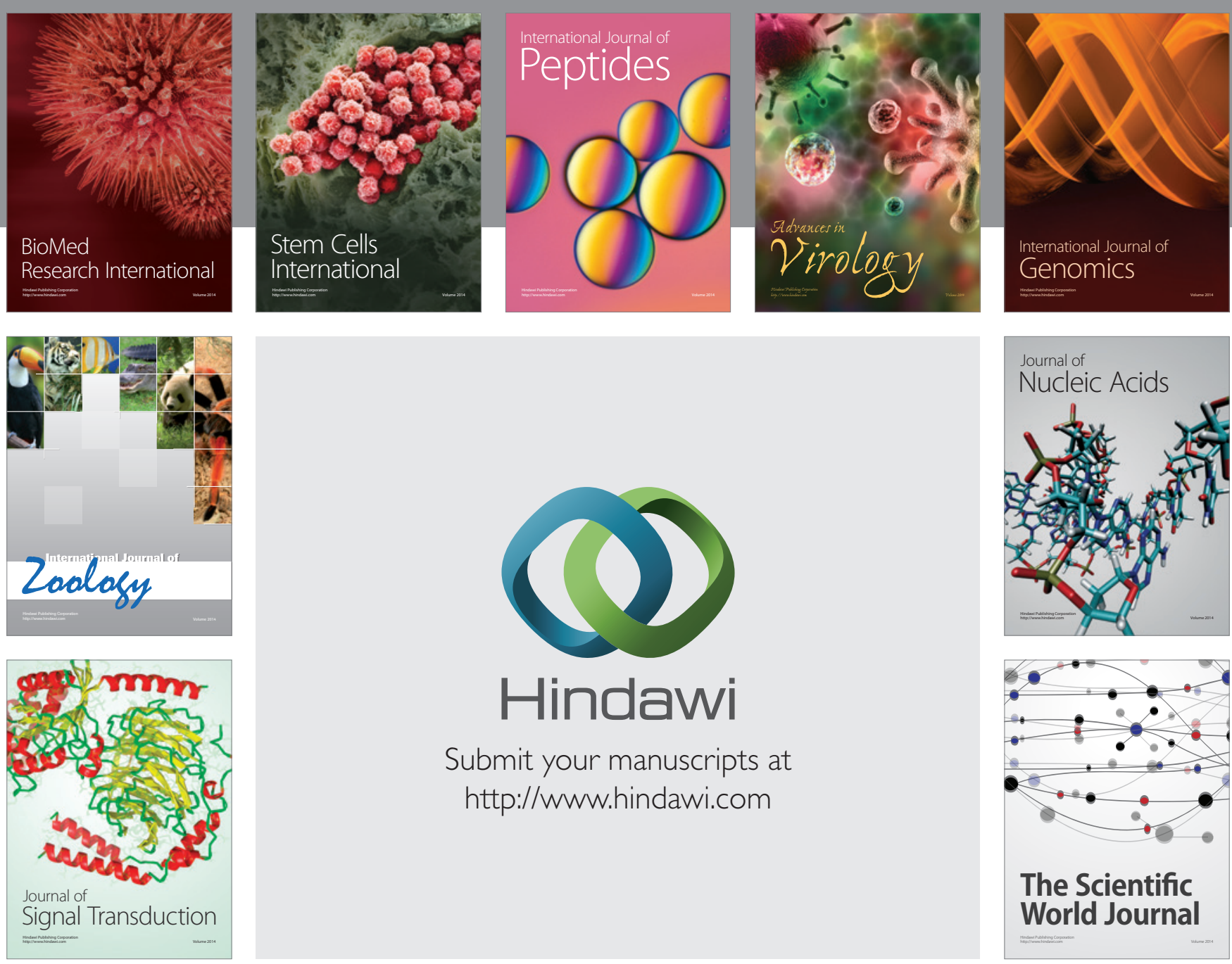

Submit your manuscripts at

http://www.hindawi.com
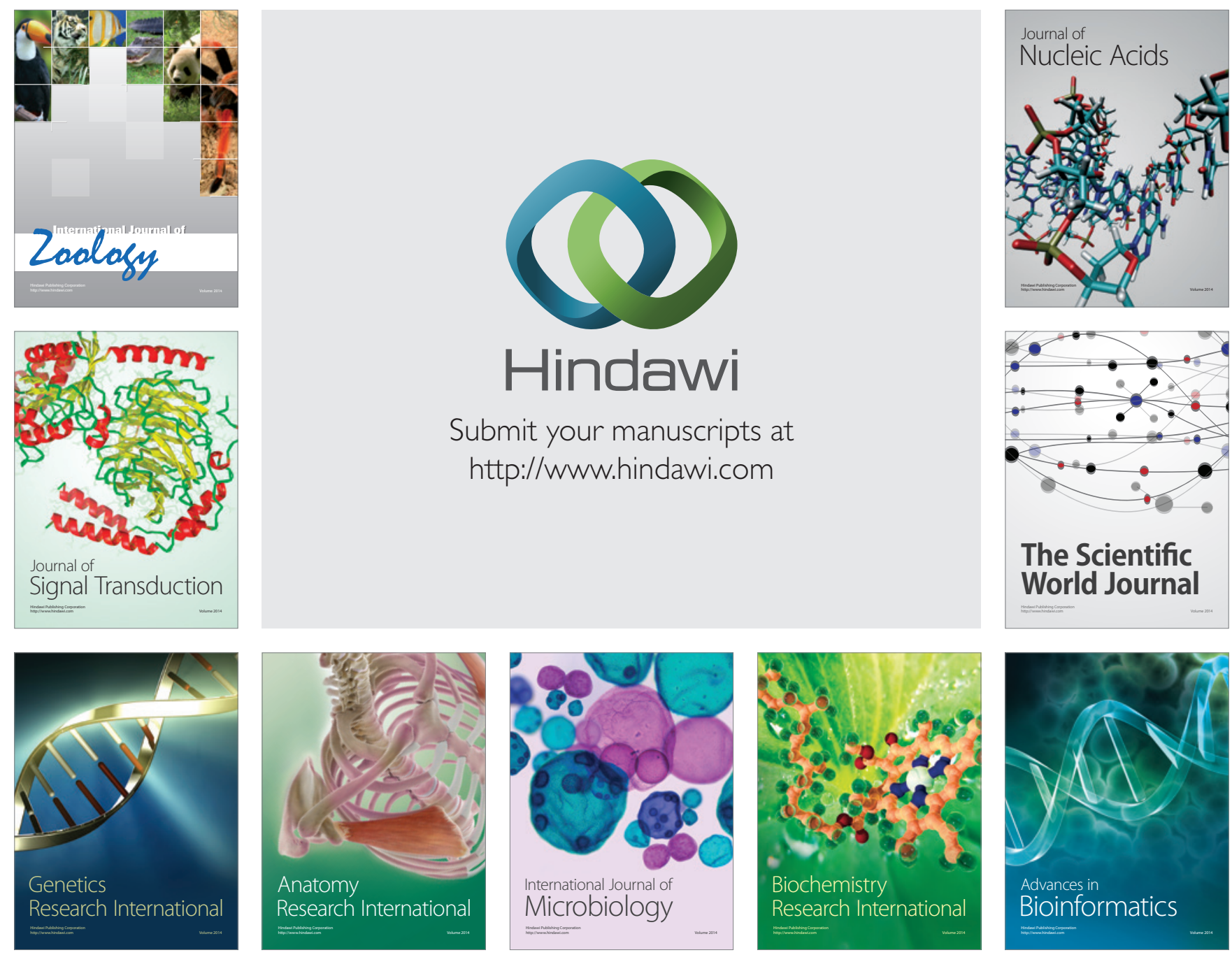

The Scientific World Journal
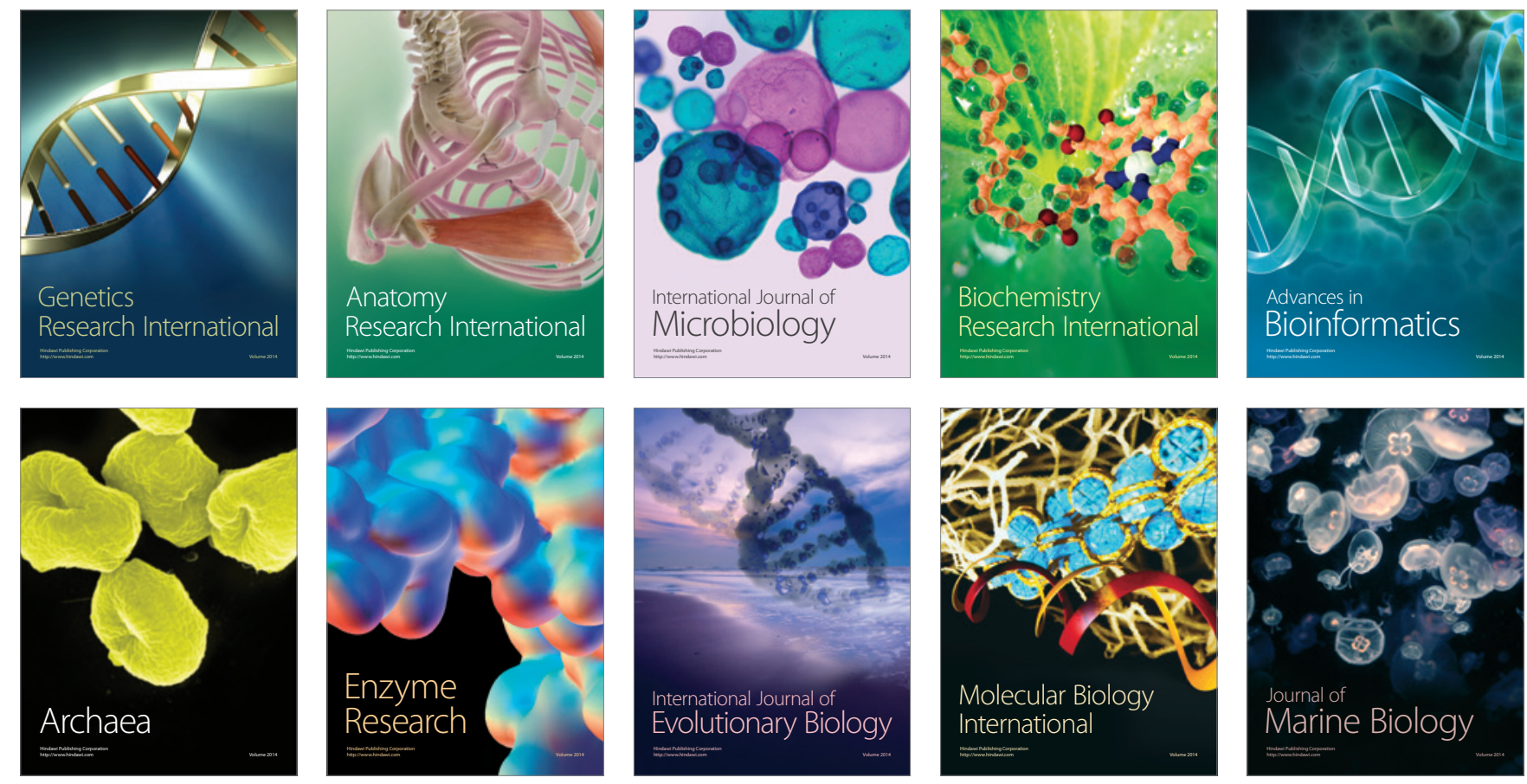